\title{
REVITALISATION OF BRANCH LINES IN SOUTH AFRICA: A LONG-TERM VIEW FOR SUSTAINABILITY
}

\author{
ZANE SIMPSON* \\ JAN HAVENGA** \\ *zane@sun.ac.za \\ **janh@sun.ac.za \\ Centre for Supply Chain Management \\ Stellenbosch University \\ South Africa
}

\begin{abstract}
South Africa's national railway management is considering the further closing of a number of branch lines due to profitability pressures from stakeholders. This paper cautions against a myopic approach to such closures. Traditionally these decisions are driven by short-term profit motives realised through resulting core line densification. The research presented in this paper demonstrates the importance of 1) taking cognisance of potential branch lines flows; 2) considering freight transport externalities and road usage costs; and 3) understanding long-term demand, in informing closure decisions. The research results reveal considerable volume opportunities for branch lines which, if captured, will significantly reduce both the direct transport costs for this traffic as well as externality charges for the economy. This will therefore not only render rural economies more competitive but also enable the provision of more sustainable freight transport to these communities. The research approach will be of value to researchers in both developed and developing economies to inform the continuous debate regarding rail rationalisation and rail revival.
\end{abstract}

\section{INTRODUCTION}

South Africa's national railway management is currently in a process of rationalising the rail network and considering the further closure of branch lines due to the current insignificant volumes transported on these lines with resulting profitability challenges. This process could however prove to be short-sighted and hamper the development of South Africa's 'second' economy, specifically the drive to develop a considerable number of South Africa's 3 million subsistence farmers, who are often within geographic reach of a branch line, into commercial farmers.

The research presented in this paper reveals the significant potential volumes available for transport on branch lines and suggests that both from a logistics cost-savings and 
development perspective, branch lines can be a viable business in the future if higher densities can be achieved on rail. This proposed shift to rail transport is aligned with the global renaissance in rail (Friends of the Earth, 2000: 5), mainly driven by the desire to reduce the externalities of freight transport. The externality challenge has prompted reaction from South Africa's Department of Transport (DoT) when it considered the condition of rural roads. The DoT announced intentions to reduce axle limits on rural roads in a bid to relieve the burden on the country's secondary road infrastructure (Fleetwatch, October 2009). The impacts of externalities as well as proposed legislative changes in axle limits are presented. From a development perspective, stakeholders need to reconsider branch line divestment if these lines give rural traffic access to main lines (Bechtel SAIC Company LLC, 2006: 8). This link between branch line and corridor (or main line) traffic for South Africa is also discussed.

\section{RESEARCH STRATEGY}

In order to analyse branch line potential, current and potential rail and road freight transport volumes and associated costs had to be determined. Rail data is available from the national railroad, but road data is not measured officially in South Africa. In order to develop road data an extensive freight flow model was developed for South Africa. This was done through the Freight Demand Model (FDM) (Havenga, van Eeden \& Simpson [FDM], 2009), a gravity model which models total freight flows in the economy based on supply and demand data for 64 commodity groups and within 356 magisterial districts. The total flow outputs of this include the freight movements of the other transport modes such as rail, coastal, pipeline and conveyer belt. The remaining flows are road flows of commodities between specific origin-destination pairs. These road flows were translated into costs based on costs per ton-km for each commodity. The costs per ton-km were calculated by allocating various vehicle combinations to each commodity on an individual basis taking into consideration various cost components such as costs of capital, licences, toll fees, insurance, driver, fuel, tyres, maintenance and repairs. This granularity was critical to enable detailed analysis of South Africa's freight transport demand. The model also contains a 30-year forecast. (Refer to Havenga, 2007, for a detailed description of the model.)

To determine potential traffic for the branch lines, road flows in the vicinity of branch lines were also analysed. Traffic flows in South Africa are determined as flows between magisterial districts (MDs). A centre point is determined for each MD. In order to analyse potential branch line flows these centre points are related to the rail network (the entire rail network for South Africa can be seen in Figure 1). This relationship is illustrated in Figure 1 in which each MD is indicated as either being on a core rail line, on a rail branch line, or having no rail access. 


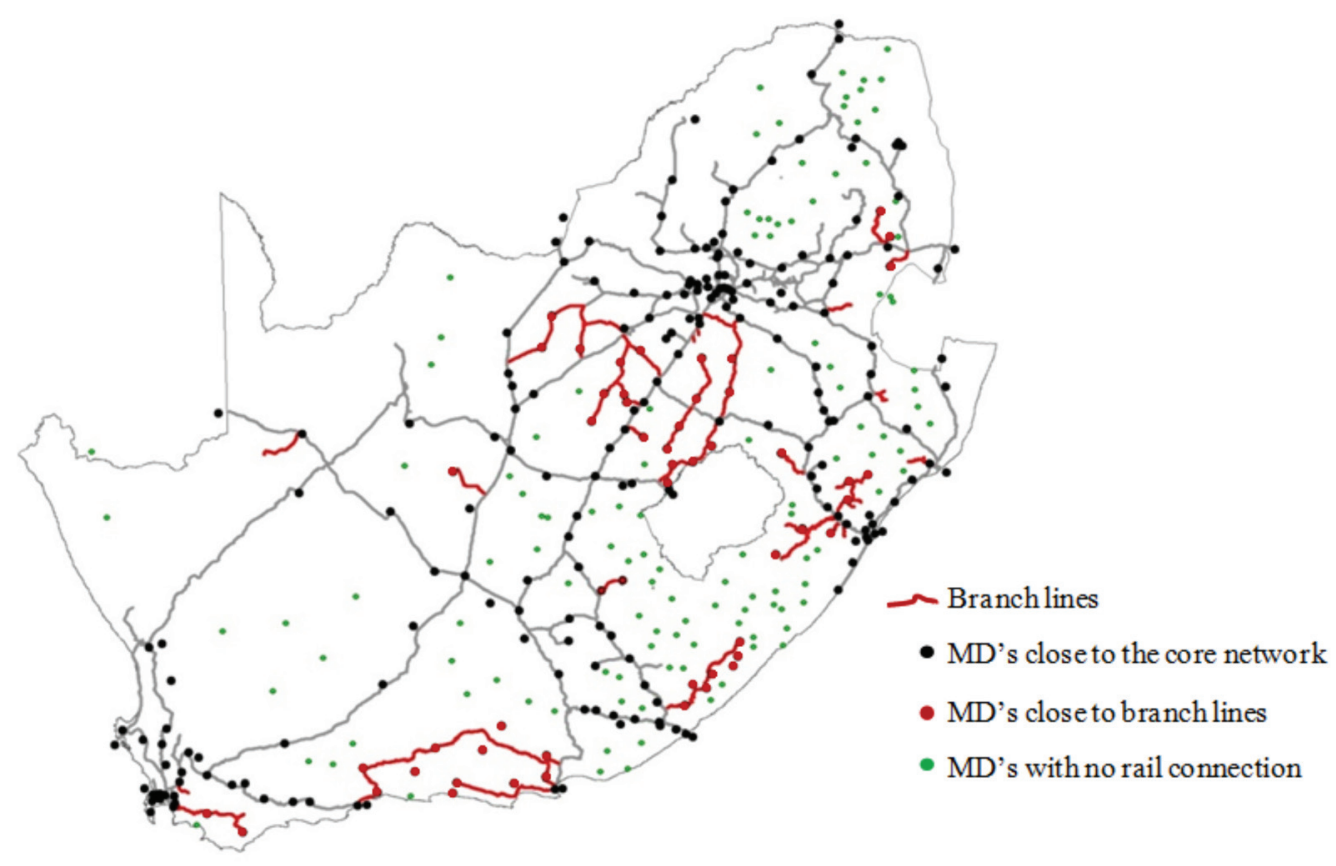

Figure 1: The relationship between magisterial districts and branch lines on the South African railway network

The resulting flows from and to MDs, both with and without access to rail according to Figure 1, are classified into four network groups as summarised in Table I.

Table I: Classification of total potential branch line-related traffic

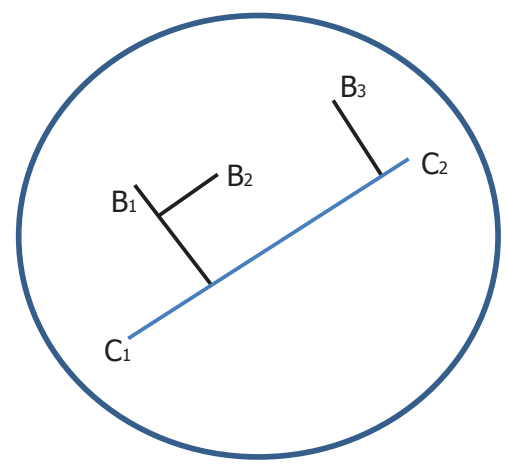

(Black lines represent branch lines; blue line represents a core line)

\begin{tabular}{|c|c|c|}
\hline Code & Description for potential traffic & Flow \\
\hline BB & $\begin{array}{c}\text { Branch-to-branch: Utilises two branch lines, } \\
\text { but not the core line }\end{array}$ & B1 to B2 \\
\hline BC & $\begin{array}{c}\text { Branch-to-core: Originates on a branch line and } \\
\text { terminates on the core line }\end{array}$ & B1 to C2 \\
\hline CB & $\begin{array}{c}\text { Core-to-branch: Originates on the core line and } \\
\text { terminates on a branch line }\end{array}$ & C1 to B3 \\
\hline BCB & $\begin{array}{c}\text { Branch-core-branch: Originates on a branch } \\
\text { line, travels some distance on the core line and } \\
\text { then utilises a second branch line }\end{array}$ & B1 to B3 \\
\hline
\end{tabular}

In cases where the branch line is very short or where traffic would only need to use a short portion of the branch line before connecting to the core line, the assumption was made that any potential traffic of this nature would rather use road transport to connect to the core line.

Externalities were determined by using rates calculated by Jorgenson (2009: 2) and applied to output results of the FDM (2009). Because of a serious lack of freight transport cost 
information in South Africa that evaluates externalities, Jorgenson (2009: 2) investigated external transport costs in a number of countries where localised or general conditions are considered to be similar to South Africa. To achieve a representative cross-section of South African transport a group of rural branch line railways and roads in KwaZulu-Natal were examined and conclusions drawn that were used to make comparisons to other important corridors or to rural areas. The externality rates of Jorgenson consists of various externalities, such as accident costs, congestion, emission, noise and policing, which together give overall externality costs. These externality costs are derived on a per ton-km basis, which were applied directly to the outputs of the FDM (Havenga et al. [FDM], 2009).

\section{DISCUSSION OF RESULTS}

\section{Potential branch line traffic}

Of South Africa's 939 million tons of total surface freight transported, 66 million tons or 7\% travels next to or on branch lines (Havenga, Van Eeden \& Simpson [FDM], 2009). (This figure is similar in ton-km terms, with approximately $8.9 \%$ of ton-km related to branch lines.) The relationship between this traffic and total traffic in South Africa is depicted in Table II.

Table II: Relationship between total traffic and potential branch line-related traffic (data source: FDM, 2009)

\begin{tabular}{|l|c|c|c|}
\hline & Tons (million) & Ton-km (billion) & ATD* \\
\hline Total SA & 939 & 297 & 318 \\
\hline Total corridor traffic & 240 & 168 & 701 \\
\hline $\begin{array}{l}\text { Potential traffic that would require a } \\
\text { proportion of branch line use: }\end{array}$ & 66 & $\mathbf{2 7}$ & $\mathbf{3 9 8}$ \\
\hline $\mathrm{BB}$ & 7 & 1 & 75 \\
\hline $\mathrm{BC}$ & 23 & 11 & 506 \\
\hline $\mathrm{CB}$ & 34 & 15 & 460 \\
\hline $\mathrm{BCB}$ & 2 & 1 & 490 \\
\hline \multicolumn{2}{|r}{} \\
\hline
\end{tabular}

This means that if branch lines were closed 66 million tons of traffic that could be transported by rail will be captured by road. Of this traffic, 57 million tons $(B C+C B)$ are potential core line traffic and can contribute to the densification (and concomitant cost savings) of the core lines. Of the 66 million tons only 9.1 million tons are currently on rail, as summarised in Table III. Rail traffic in South Africa declined and has been captured by road for various reasons. These include an increasing backlog in rail investment causing deteriorating service levels and declining capacity over the past 10 years (Swiss Business Hub South Africa, 2009). The further lack of intermodal facilities has resulted in road transport growth on corridors. Rail branch lines have been increasingly abandoned to improve overall density of the rail system. 
Table III: Rail market share of potential branch line traffic (data source: FDM, 2009)

\begin{tabular}{|l|c|c|c|c|c|c|}
\hline & $\begin{array}{c}\text { Total tons } \\
\text { (millions) }\end{array}$ & $\begin{array}{c}\text { Rail tons } \\
\text { (millions) }\end{array}$ & $\begin{array}{c}\text { Total ton-km } \\
\text { (billions) }\end{array}$ & $\begin{array}{c}\text { Rail ton-km } \\
\text { (billions) }\end{array}$ & Road ATD & Rail ATD \\
\hline $\mathrm{BB}$ & 7.3 & 1.8 & 0.5 & Neg & 69.1 & 21.8 \\
\hline $\mathrm{BC}$ & 23.4 & 4.1 & 10.5 & 1.3 & 449.1 & 324.5 \\
\hline $\mathrm{CB}$ & 33.7 & 3.2 & 14.5 & 1.0 & 431.1 & 302.9 \\
\hline $\mathrm{BCB}$ & 2.0 & 0.1 & 1.0 & $\mathrm{Neg}$ & 466.9 & 469.9 \\
\hline All B inclusive & $\mathbf{6 6 . 4}$ & $\mathbf{9 . 1}$ & $\mathbf{2 6 . 5}$ & $\mathbf{2 . 4}$ & & \\
\hline
\end{tabular}

Only $11 \%$ of potential tons shipped encompass a single branch line system (BB). As average transport distances are low for traffic that originates and terminates on the same branch line, only $1.9 \%$ of potential ton-km are enclosed within a single branch line system. The 2008 cost to transport branch line-related traffic amounted to R19 billion (or 11\% of South Africa's 2008 transport bill of R171 billion) (Havenga, Van Eeden \& Simpson [CSCM Cost Model], 2009). The branch line transport bill for rail is less than R1 billion (0.5\%) of this total.

Rail's role in branch line-related transport is therefore currently negligible with $14 \%$ of tons, $9 \%$ of ton- $\mathrm{km}$ and $0.5 \%$ of costs on rail (Figure 2). It also implies that there is a significant opportunity available.

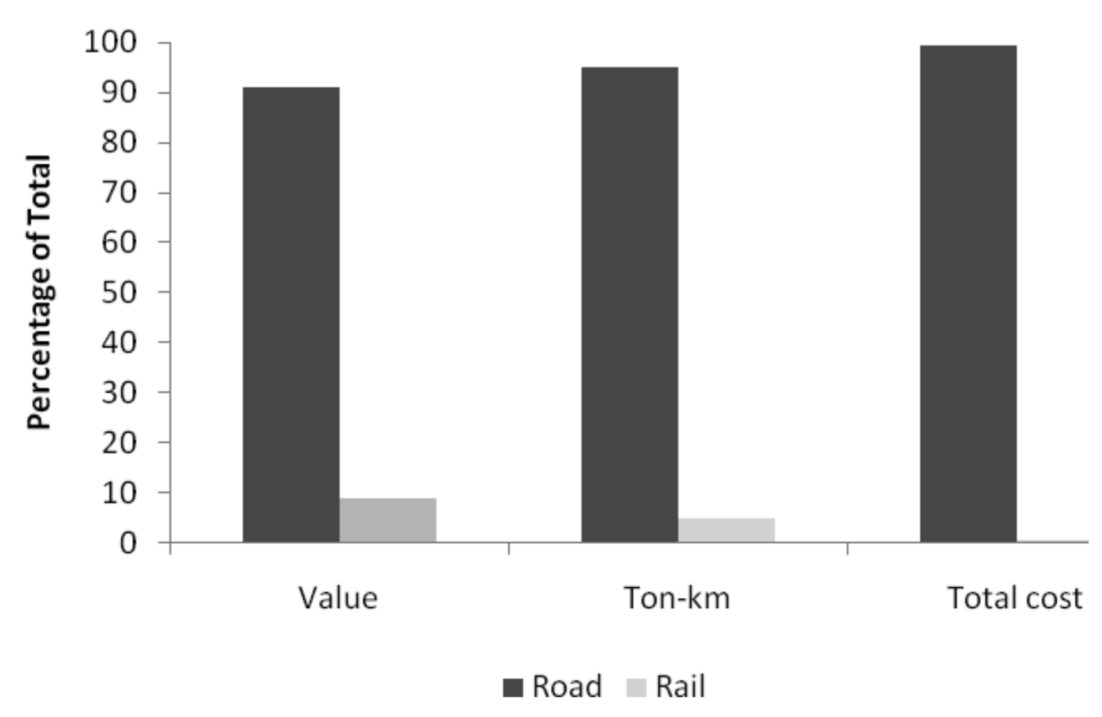

Figure 2: Rail's negligible role in branch line-related traffic (data source: FDM, 2009, and CSCM Cost Model, 2009)

This potential could be realised by improving rail's service offering (which is a relatively small cost compared to the fact that the infrastructure already exists) but more importantly through measuring and costing for externalities (inter alia through legislation) to ensure sustainable service provision to this traffic. 


\section{Switching scenarios - shifting rural freight to rail}

Two scenarios for the switching of road traffic next to branch lines were conducted based on workshops with industry specialists in October 2009 (Table IV), considering variable market share percentages per cargo type. These two scenarios considered the most optimistic achievement of rail (scenario 1, being able to target short-distance freight and high-market shares), as well as a realistic target (scenario 2, being longer distance freight, with current market shares increased slightly to round numbers).

Table IV: Market share scenarios for switching traffic to branch lines

\begin{tabular}{|c|c|c|c|}
\hline \multicolumn{2}{|c|}{$\begin{array}{l}\text { Scenario } 1=\text { High switching } \\
\text { scenario with ATD }>100 \mathrm{~km}\end{array}$} & \multicolumn{2}{|c|}{$\begin{array}{l}\text { Scenario } 2=\text { Low switching } \\
\text { scenario with ATD }>500 \mathrm{~km}\end{array}$} \\
\hline Automotive & $0 \%$ & Automotive & $0 \%$ \\
\hline Break bulk & $50 \%$ & Break bulk & $10 \%$ \\
\hline Dry bulk & $75 \%$ & Dry bulk & $25 \%$ \\
\hline Liquid bulk & $25 \%$ & Liquid bulk & $0 \%$ \\
\hline Perishables & $0 \%$ & Perishables & $0 \%$ \\
\hline
\end{tabular}

When applying the analysis of the switching scenarios, of the 66 million tons of potential traffic next to branch lines, a maximum of 29.3 million tons could move to rail (under scenario 1). Of this, only 4 million tons will be enclosed within the same branch line system. The rest of the traffic will require the core network. If this traffic switches, total branch line-related traffic will be 38.4 million tons (rail market share of 58\%) of which $85 \%$ (32.6 million tons) will require the core network (Table $\mathrm{V}$ ).

Table V: Scenarios for switching traffic (data source: FDM, 2009)

\begin{tabular}{|l|c|c|c|c|c|c|}
\hline & $\begin{array}{c}\text { Total tons } \\
\text { (millions) }\end{array}$ & $\begin{array}{c}\text { Total } \\
\text { rail tons } \\
\text { (millions) }\end{array}$ & $\begin{array}{c}\text { Switchable } \\
\text { rail tons } \\
\text { scenario 1 } \\
\text { (millions) }\end{array}$ & $\begin{array}{c}\text { Switchable } \\
\text { rail tons } \\
\text { scenario 2 } \\
\text { (millions) }\end{array}$ & $\begin{array}{c}\text { Total rail } \\
\text { tons after } \\
\text { scenario 1 } \\
\text { (millions) }\end{array}$ & $\begin{array}{c}\text { Total rail } \\
\text { tons after } \\
\text { scenario 2 } \\
\text { (millions) }\end{array}$ \\
\hline BB & 7.3 & 1.8 & 4.0 & 1.3 & 5.8 & 3.1 \\
\hline BC & 23.4 & 4.1 & 9.5 & 2.6 & 13.6 & 6.8 \\
\hline CB & 33.7 & 3.2 & 14.7 & 3.4 & 17.9 & 6.6 \\
\hline BCB & 2.0 & 0.1 & 1.0 & 0.3 & 1.1 & 0.4 \\
\hline All B inclusive & $\mathbf{6 6 . 4}$ & $\mathbf{9 . 1}$ & $\mathbf{2 9 . 3}$ & $\mathbf{7 . 6}$ & $\mathbf{3 8 . 4}$ & 16.8 \\
\hline
\end{tabular}

There is therefore significant opportunity available to rail through improved service provision. Appropriate regulation could, however, further improve this position. One option currently 
being considered is the reduction of the axle mass limit on rural roads to decrease the wear and tear on roads.

\section{Cost impact of proposed axle limit change}

The road transport axle limit reduction from 9 tons to 8 tons per axle will have a considerable effect on transport costs. This would require a consignment of 18 tons, ${ }^{1}$ which can currently be transported on a double-axle truck, to be transported either by two trucks or a threeaxle truck. This will greatly increase the number of vehicles required, number of trips, and running costs. Vehicle types that are now used for specific freight commodities will no longer be optimal, and especially high capacity vehicles will not be able to reach even close to maximum payload. The road transport costs will be greatly affected by such a change. Total road transport costs for traffic in the vicinity of branch lines is expected to increase by R1 billion from R10.3 billion to R11.3 billion if this change is implemented (Figure 3).

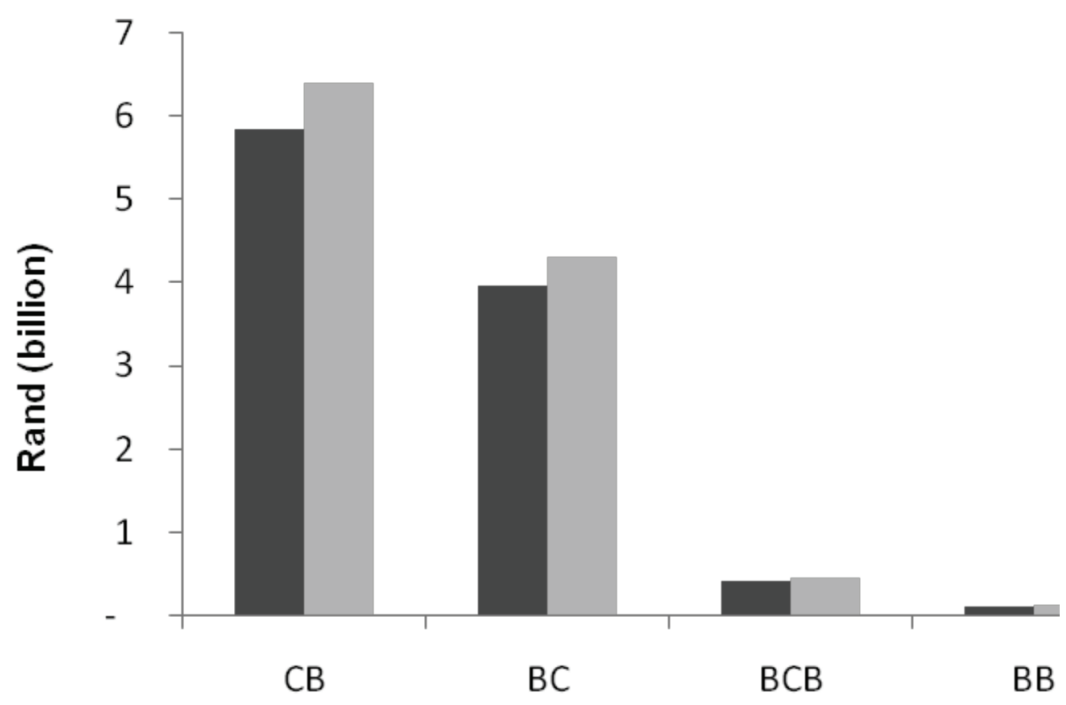

Figure 3: Road transport cost increases per flow type if axle limit change is implemented (data source: FDM, 2009, and CSCM Cost Model, 2009)

If the switch to rail transport presented in the previous section occurs, total transport costs (assuming that commodities can be transported at current rail tariffs) will however be lower. Current branch line-related transport costs are R18.8 billion, while with the proposed scenarios 1 and 2, they would be R17.6 billion and R18.5 billion respectively (Figure 4).

1 Actual weight of the vehicle is not taken into consideration. 


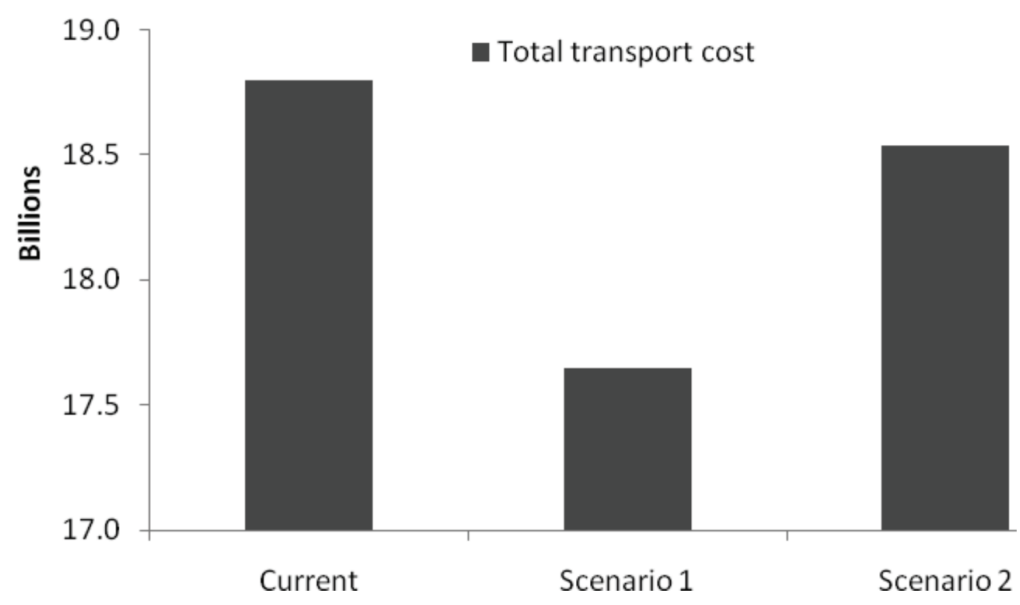

Figure 4: Comparative total transport costs: current vs. scenarios 1 and 2 (data source: FDM, 2009, and CSCM Cost Model, 2009)

This means that although road transport costs will increase (a fact that is causing obvious concern for freight owners), improvements in rail service that will make the switch palatable will decrease the total transport bill of the nation.

As discussed in the next section, understanding externalities and the costing for these could provide further inducements for a modal shift.

\section{Cost impact of externalities}

The branch line-related externality costs of R3.8 billion are almost entirely a result of road use (rail's externality costs amount to a mere R38.6 million or $1 \%$ of the total). The current externality costs will be reduced by 35\% in scenario 1 (to R2.5 billion) and $8 \%$ in scenario 2 (or R3.5 billion) as illustrated in Figure 5.

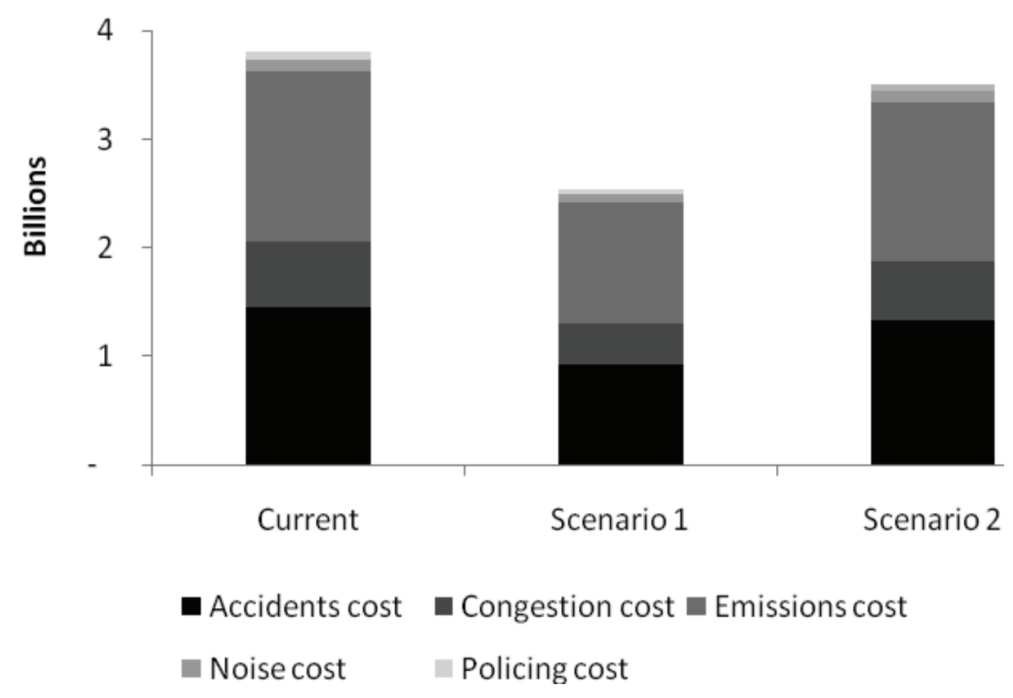

Figure 5: Comparative externality cost components: current vs. switching scenarios (data source: FDM, 2009, and CSCM Cost Model, 2009) 
Total transport costs for branch line traffic (with externalities included) will therefore reduce from R22.6 billion to R20.2 billion in scenario 1 (an 11\% reduction) and R22.0 billion in scenario 2 (a $3 \%$ reduction), as depicted in Figure 6.

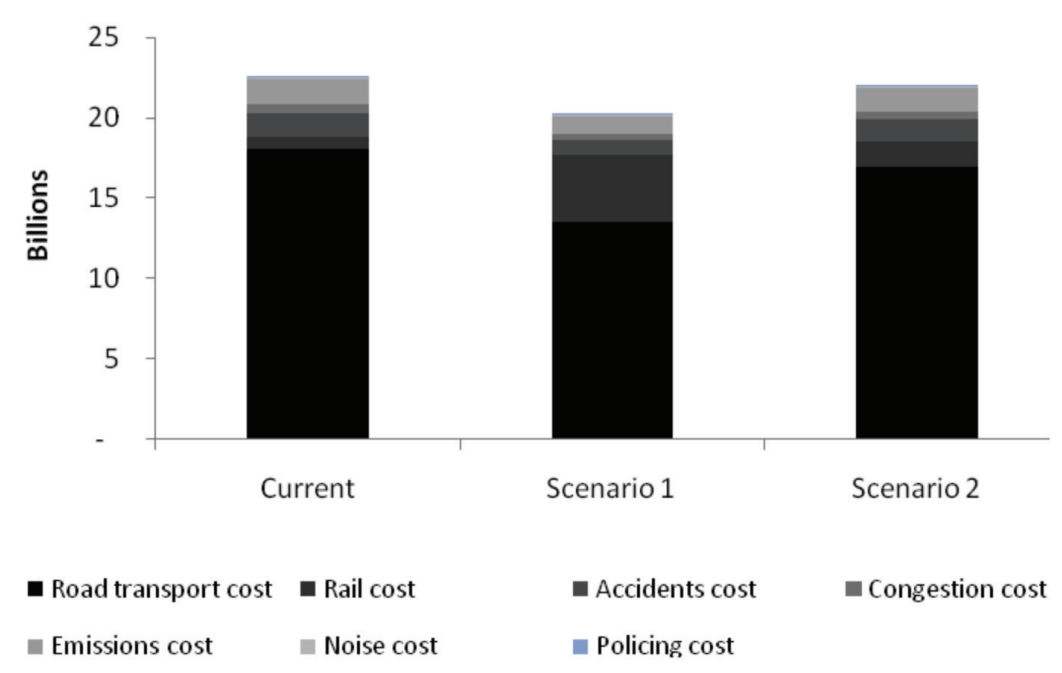

Figure 6: Comparative cost components: current vs. switching scenarios (data source: FDM, 2009, and CSCM Cost Model, 2009)

This means that with an improved service offering, regulation (which is required to protect the pavement surface) and externality accounting, a branch line modal shift will substantially decrease the nation's freight bill.

\section{A view of the future}

Future demand (between 5 and 30 years) can be calculated using the FDM and cost savings determined for the high switch scenario and calculated in today's real monetary value i.e. the effect of inflation is not considered for both costs and income. The total branch line-related tons transported is forecast to be 139.9 million tons (compared to the current 66.4 million tons) and 56.1 billion ton-km (compared to the current 26.5 billion ton-km). The application of the two previously developed scenarios to the higher future volumes point to considerable densification potential for rail, which in turn enables exploitation of rail's significant economies of density (rail's cost savings are exponential with increases in density) (Harris, 1977; Mercer, 2002). These cost savings are 15\% in scenario 1 and 5\% in scenario 2, as illustrated in Figure 7. 


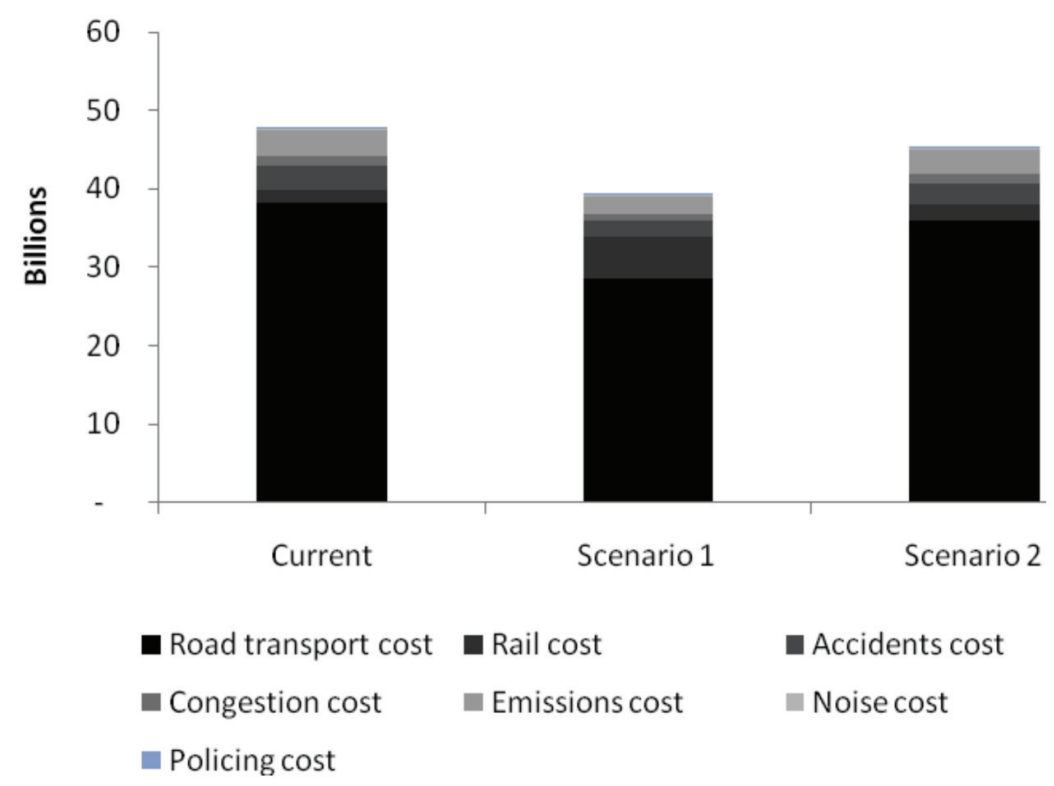

Figure 7: Future comparative cost components: current vs. switching scenarios (data source: FDM, 2009, and CSCM Cost Model, 2009)

These scenarios illustrate the significant cost-savings potential if a future view is taken. These savings will only be possible if the branch lines remain in operation because of the prohibitive cost of reviving these lines in future.

\section{CONCLUSION}

The research illustrated that there are significant volumes available for branch line transport. A switching of these volumes to rail will reduce both transport costs and externality charges, rendering this transport mode more competitive. The savings become even more considerable if road axle limits are reduced, or if other pressures are placed upon transportation such as possible government regulation on certain mining commodities being enforced to be transported on rail. Other measures which are becoming commonplace in the developed countries are externality charges, tighter control on overloading and increased rail investment, which could further induce modal shift.

The research also points to the integrated and 'single network' characteristic of South Africa's railway system. Very few branch lines operate in 'separate' economic pockets or development areas. Concessioning the lines to different operators for the purpose of isolated operation is therefore questioned. Concessioning of branch lines should be done with a view of integrating services into the core network. Finally, a future view of demand and the correct accounting for externalities illustrate the viability of branch lines. 
Many countries around the world closed similar lines down and costly efforts are currently underway to revive these lines. ${ }^{2}$ South Africa has the opportunity to avoid going down this road by basing its decisions on the future of branch lines on long-term sustainability rather than short-term gains.

2 One of the most well-known rationalisation attempts is the "Beeching Axe" in the United Kingdom which was proposed by Dr Richard Beeching in the 1960s. It led to the reduction of $25 \%$ of route miles, mainly on branch lines, some of which have now reopened and with more destined for reopening, but at great cost and difficulty. Very little real cost savings were achieved by the closures. Many such examples exist around the world. 


\section{REFERENCES}

Bechtel SAIC Company LLC. 2006. Mina Rail Route Feasibility Study.

Fleetwatch. October 2009. DOT proposal sparks outrage. Available from: http://www. fleetwatch.co.za/magazines/Oct2009/18-DoT\%20proposal\%20sparks\%20outrage.htm (accessed on 6 July 2010).

Friends of the Earth: Northern Ireland. 2000. Out of the shadows: The future of Northern Ireland's railways, Belfast.

Harris, R. G. 1977. Economics of traffic densities in the rail freight industry. Bell Journal of Economics, 8(2): 556-64.

Havenga, J. H. 2007. The development and application of a freight flow model for South Africa. Unpublished doctoral thesis, Stellenbosch University.

Havenga, J. H., Van Eeden, J. \& Simpson, Z. (CSCM Cost Model). 2009. The Centre for Supply Chain Management Cost Model. Stellenbosch. Unpublished internal project documentation.

Havenga, J. H., Van Eeden, J. \& Simpson, Z. (FDM). 2009. Transnet freight demand model (FDM). Stellenbosch. Unpublished internal project documentation.

Jorgenson, A. 2009. Transport costs and the relevance of externalities. Discussion paper, Africa Rail, 25 June 2009.

Mercer, 2002. Infrastructure separation and open access: Lessons from experience. Unpublished confidential report.

Swiss Business Hub South Africa. 2009. South Africa infrastructure report, Feb 2009. 